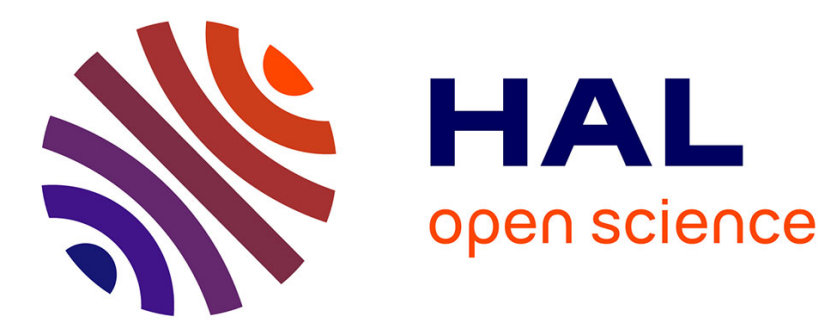

\title{
The self-propagating high-temperature synthesis of sinterable powders
}

\author{
R. Pampuch
}

\section{To cite this version:}

R. Pampuch. The self-propagating high-temperature synthesis of sinterable powders. Journal de Physique IV Proceedings, 1993, 03 (C7), pp.C7-1277-C7-1285. 10.1051/jp4:19937197 . jpa-00251830

\section{HAL Id: jpa-00251830 https://hal.science/jpa-00251830}

Submitted on 1 Jan 1993

HAL is a multi-disciplinary open access archive for the deposit and dissemination of scientific research documents, whether they are published or not. The documents may come from teaching and research institutions in France or abroad, or from public or private research centers.
L'archive ouverte pluridisciplinaire HAL, est destinée au dépôt et à la diffusion de documents scientifiques de niveau recherche, publiés ou non, émanant des établissements d'enseignement et de recherche français ou étrangers, des laboratoires publics ou privés. 


\title{
The self-propagating high-temperature synthesis of sinterable powders
}

\section{R. PAMPUCH}

Department of Advanced Ceramics, AGH, Kraków, al. Mickiewicza 30, Poland

\begin{abstract}
The present overview focuses on self-propagating high-temperature synthesis (SHS) of powders for the standard processing of ceramics by sintering or hot-pressing. An impact of SHS on ceramic materials technology depends largely on its capability to produce powders that have a densification behaviour comparable to or better than the conventionally produced ones. The paper points to the fact that substitution of the conventional powders by the SHS-derived ones results in higher density and more homogeneous microstructure, at least with nitride and carbide powders that are notorious for their bad sinterability. The first part of the paper deals with the general features of SHS. The specific mechanism of SHS reactions is the object of the second part of the paper. Part three of the paper presents the sintering characteristics of powders produced by SHS in the Si-C-B, Si-N, Si-Al-O-N, and Ti-C-Si systems.
\end{abstract}

\section{Introduction}

Figure 1 schematically represents the principle of self-propagating high-temperature synthesis, in short SHS. In the self-propagating regime of SHS, preheating one end of a reactant mixture initiates an exothermic reaction. Once initiated, the reaction becomes self-sustaining and the hot reaction zone propagates through the sample, leaving in its wake the final solid product. More uniform preheating of the whole sample is used in the thermal explosion regime of SHS. Here, the changes shown in Fig. 1 refer to a given small volume of the sample and the $x$-axis represents the time.

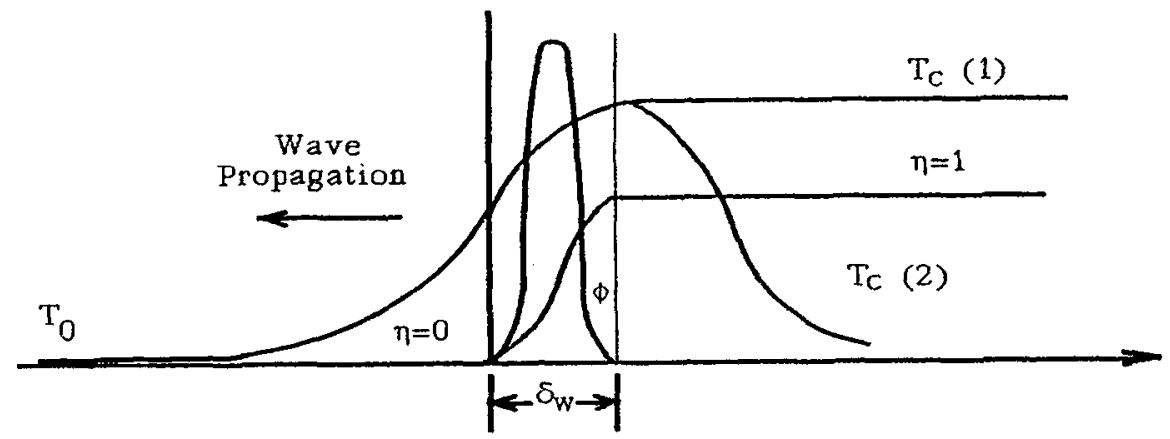

Fig. 1. Schematic representation of the temperature, $T$, degree of advancement of the reaction, $\eta$, and rate of heat generation, $\Phi$, on propagation of the combustion wave in the self-propagating regime of SHS. 
To realise this principle it is necessary that the rate of reaction heat release exceeds the rate of heat losses to the environment. These conditions correspond to positive feedback (Figure 2). Namely, an increase of the temperature increases in the turn the rates of reaction and heat release. This ensures that the reactive system reaches rapidiy high temperatures at which fast reactions become possible.

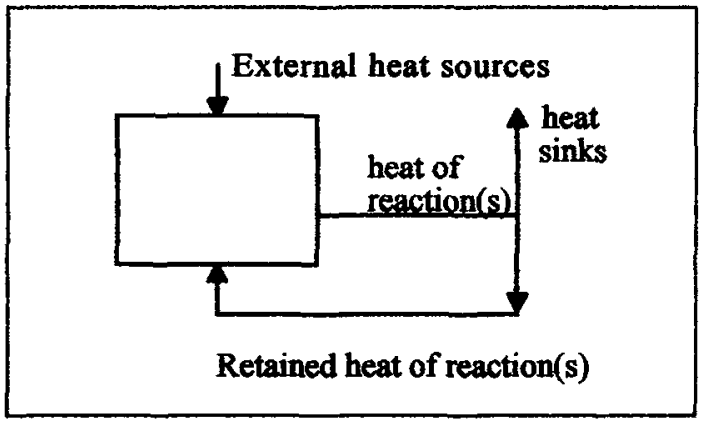

Figure 2. The logical scheme of SHS

The energy from internal heat sources, i.e. heat of exothermic reactions, furnishes $50-98 \%$ of the total energy needed for the synthesis. In this respect SHS is placed between the processes in explosives and the processes utilising exothermic reactions in more conventional ceramic technologies (Figure 3).

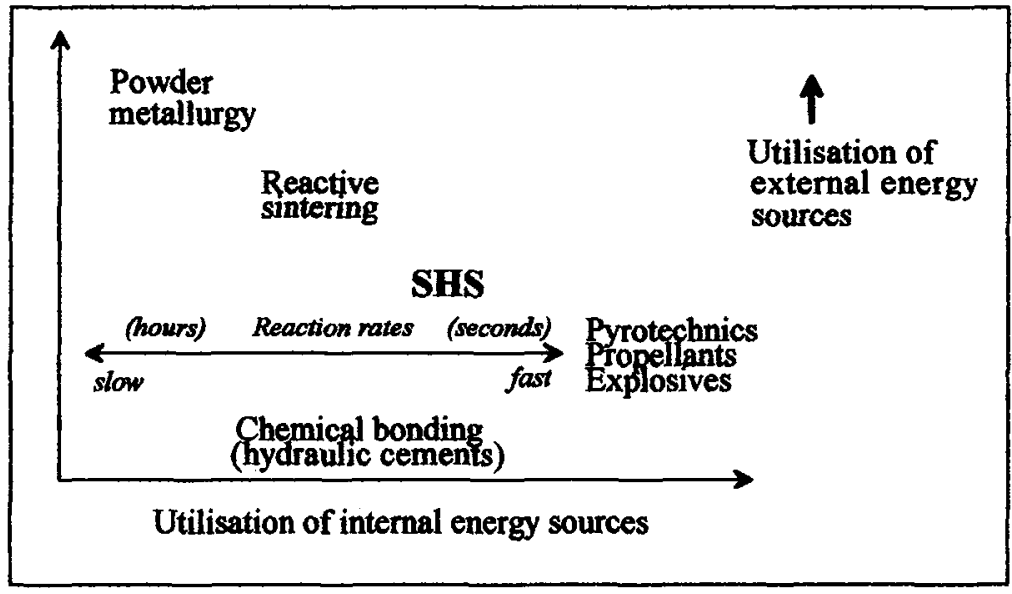

Figure 3 The general characteristics of SHS in comparison with other processes making use of exothermic reactions, according to an idea in Ref.[1]

Exothermic reactions used in SHS may be classified roughly in three types:

reactions of compound formation from the elements; thermite type reactions; reactions that are a combination of the former two types (see also Fig.4). Such reactions are very many. Since the publication of the consequential paper by Merzhanov and Borovinskaya [2], reports about SHSynthesis of several hundreds of refractory ceramic and metallic compounds in powder and in consolidated form appeared. These are well covered by several overviews [3]-[5]. The widespread interest in using SHS is due to the potential advantages that result from the before presented features of SHS. These are: efficient utilization of reaction energy and economy of external energy; high speed of the process; the synthesis may be complete in minutes if not in seconds; purification of the resulting products owing to partial volatitisation of impurities. 
Figure 4 shows some of the applications of SHS. These include production of powders of refractory nitride, carbide, boride, silicide powders, intermetallic compounds, among them shape-memory alloys, and ceramic particulate composites. The method has been used to produce metal-ceramic materials, especially the functional gradient materials [6] for which SHS is the unique producing method. An important application of SHS is the joining of ceramics with ceramics and metals, and the joining of metals.

\section{Types of reactions:}

1.Compound formation 2. Thermite reactions 3.Combination of 1 \& 2

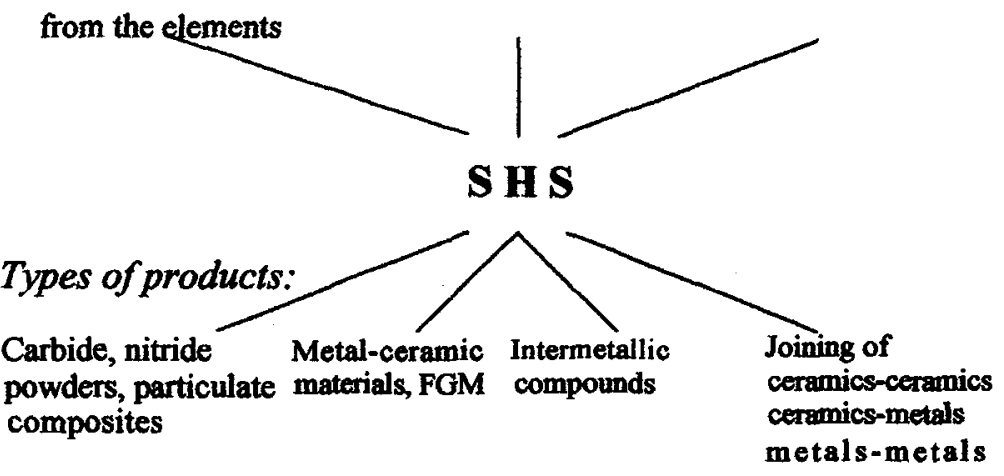

Figure 4. Some of the applications of SHS

The present paper is focused on the application of SHS in the area of powders for the standard ceramic processing. That is, for processing involving powder preparation, their comminution, and densification, first by cold-forming and next by sintering or hot-pressing. This processing is and shall remain the main method of production of ceramic materials, and a chance for broader use of SHS is linked with its application to produce powders. From the general characteristics of SHS follow already two advantages of such an application. Namely: the simplicity of installations leading to low investment and operational costs; 1 the purity of powders in comparison with the starting materials.

According to data about $\mathrm{SiC}$ and $\mathrm{TiC}$ powders of different origin (Table 1), the contents of major impurities are indeed lower in the SHS-derived powders than in the ones produced by other advanced methods. In addition to these data it is also worth mentioning that SHS yields many carbide and nitride powders in form of soft agglomerates that may be easily comminuted. The powdering results in a narrow particle size distribution and the mean particle size is not to small and not too coarse. Such characteristics confer to the SHS powders an excellent cold-pressability. Therefore, two other advantages may be added: easy comminution; excellent cold-pressability. These powder characteristics are important, because elevated costs of comminution together with a high price of the raw-materials may nearly offset the gains in external energy consumption during the SHsynthesis itself [8].

In the present paper another aspect shall be stressed, namely the densification behaviour of the SHS-derived powders. This aspect has attracted little attention in previous papers of other authors involved in SHS research. What is more, opinions may be heard that from this point of view the SHS-derived powders are inferior to the conventionally produced ones [9][10]. However, the work made in our Department and in the NY State University at Buffallo furnishes ample experimental evidence indicating that these opinions are quite opposite to the reality. The earliest reports about sinterable SHS-derived powders appeared in Refs. [11]-[13]; further references shall be discussed in part 3. 
Table 1. Some characteristics of TiC and SiC powders produced by SHS, and other advanced methods of synthesis [7]

\begin{tabular}{|c|c|c|c|c|c|}
\hline Powder / method & $\begin{array}{l}\text { Mean } \\
\text { particle } \\
\text { size [ } \mu \mathrm{m}]\end{array}$ & $\begin{array}{c}\text { BET } \\
\text { surface } \\
\text { area } \\
{\left[\mathrm{m}^{2} / \mathrm{g}\right]}\end{array}$ & $\begin{array}{c}\mathrm{C} \\
{[\mathrm{wt} \%]}\end{array}$ & $\begin{array}{c}\mathrm{O} \\
{[\mathrm{wt} . \%]}\end{array}$ & $\begin{array}{l}\mathrm{Me} \\
{[\mathrm{wt} \% \text { ] }}\end{array}$ \\
\hline TiC: SHS & 0.5 & 1.1 & 0.07 & 0.55 & 0.15 \\
\hline Fumace synthesis & 1.3 & 0.8 & 0.25 & 0.75 & 0.5 \\
\hline Plasmochemical & 0.06 & 23 & 0.08 & 2.3 & 0.3 \\
\hline (.................... & ….... & (n............. & ……......... & …........... & (n........ \\
\hline SiC:SHS & 0.2 & $(15.0)$ & $<0.1$ & $<0.3$ & 0.1 \\
\hline Acheson (modernized) & 1.6 & $(1-15)$ & ND & 1.0 & 0.3 \\
\hline Carbothermic reduction & 2 & $5-15$ & 0.6 & 0.02 & $<0.2$ \\
\hline Laser-driven synthesis & 0.02 & 97.5 & ND & 1.45 & 4.5 \\
\hline
\end{tabular}

Remarks: ND - not determined; Me -metallic impurities; BET surface area in parentheses -after grinding.

The characteristics of SHS-derived powders, including their densification behaviour, is due to the specific mechanism of SHS reactions, and these shall be now recalled shortly.

\section{The mechanism of SHS reactions}

It is extremely difficult to make direct observations under SHS conditions. Therefore, the knowledge about the SHS reactions is based mainly on thermodynamic and kinetic models. The models must, of course, explain also the reasons for the occurrence of self-sustaining reactions. The kinetic model of SHS reactions in the carbide systems has been developed for the relatively simple Si-C system, for which the necessary solubility and diffusivity data are known. Model calculations of the solid-state reaction and of the dissolution kinetics in Ref. [14] have permitted to identify three temperature ranges. In each of the temperature ranges a different reaction mechanism has been found to be predominant.

At temperatures below $1900^{\circ} \mathrm{C}$ a solid $\mathrm{SiC}$ reaction layer between the reactants should form and grow in thickness with time, irrespective whether the silicon is solid, becomes liquid above $1410^{\circ} \mathrm{C}$, or is in the gaseous phase. It constitutes a diffusional barrier, because the diffusion coefficients of $\mathrm{C}$ and $\mathrm{Si}$ in $\mathrm{SiC}$ are extremely low. Between 1900 and $2100^{\circ} \mathrm{C}$ the growth rate of $\mathrm{SiC}$ at the carbon/SiC interface is very close to the dissolution rate of $\mathrm{SiC}$ in liquid silicon at the opposite SiC/liquid Si interface. In this temperature range the reaction layer should retain therefore its small initial thickness during the whole synthesis. On the one hand, this signifies a migration of thin reaction layer inside the solid carbon reactant, the layer training in its wake the carbon solution in liquid silicon. On the other, it means a formation of the final product (secondary SiC) by precipitation from the supersaturated liquid solution. This should occur in sites previously occupied by the not fusible carbon reactant. The idea is presented in Figure 5. A mechanism involving growth of the reaction layer at the solid/solid interface and its concomitant dissolution at the opposite liquid metal/solid interface has been observed in metal-carbon or boron systems other than Si-C, under conditions akin to SHS [15]. Due to the higher rates of dissolution of C and $\mathrm{SiC}$ in liquid silicon, above $2100^{\circ} \mathrm{C}$ a direct dissolution of $\mathrm{C}$ should occur. Precipitation from the supersaturated liquid solution is also here the obvious mechanism of formation of SiC. In contrast to conventional furnace heating, SHS permits to pass rapidly over the range of lower temperatures. Therefore, it allows to avoid the growth of a thick reaction layer and favours the occurrence of the two dissolution- precipitation mechanisms mentioned. 


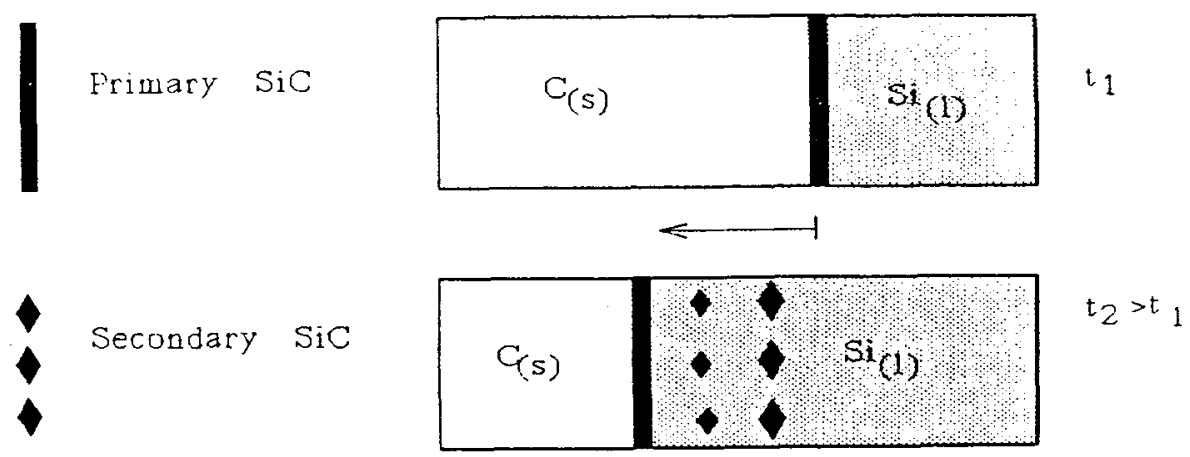

Figure 5. Schematic representation of the reaction mechanism in the Si-C system under SHS conditions at elevated temperatures, according to [14]

There is a growing body of experimental data on SHS in metal-carbon and boron systems that point to the mechanisms envisaged in the above presented model. In the Si-C system, the products form metamorphoses of the solid carbon reactant, be it fibres, charcoal, or carbon black [11][16]. The mechanism involving migration of a thin reaction layer into the carbon particles allows a rational explanation of these observations. According to model calculations, this mechanism should predominate at temperatures between 1900 and $2100^{\circ} \mathrm{C}$. It is precisely the range of the peak temperatures of SHS in the Si-C system [16][17]. Macrokinetic investigations permitted to determine the activation energy of SiC synthesis under SHS conditions [18]. The energy found is equal to the one of solution of SiC in liquid Si. In this light it is natural to assume that dissolution and precipitation of $\mathrm{SiC}$ take place simultaneously on SHS, the limiting step being diffusion of $\mathrm{C}$ in liquid $\mathrm{Si}$. Also in the $\mathrm{TiC}$ system a change in the activation energy of SHS synthesis of TiC has been found at elevated temperatures [19] which is believed to signify a shift from solid-diffusion to solution-precipitation controlled process.

The mechanism of reactions on SHS of intermetallic compounds, such as nickel or copper aluminides, is similar and involves both solid-state reactions and formation of a liquid through a eutectic reaction. The final solid product is also formed in liquid-phase reactions [20]. The SHS of nitrides, based on reactions between metals and gaseous nitrogen, is more complex [4]. This is in part due to the nature of the phase equilibria between nitrogen and the refractory metals, especially to the formation of large regions of solid solutions. In addition to forming solid solutions, the nitrides may undergo thermal dissociation to gaseous elements, because of the high temperatures attained here on SHS. Therefore, liquid- and gaseous-phase reactions should play a major role in SHS of nitrides, irrespective of the exact mechanism.

One can see from this short recapitulation that the common factor of SHS is the minor role of formation of thick reaction layers. Since such layers constitute a diffusional barrier, the SHS may be fast and self-sustaining. Another common factor is the formation of intermediary solutions, be it liquid or solid In either case this provides a way for producing complex powdery materials. SHS is indeed able to produce complex phases and solid solutions with high solute contents that are exotic with the conventional processes. This is important in the context of production of powders for sintering. On the one hand, powders of solid solutions are usually more active on sintering than undoped compounds. On the other, SHS enables to produce in situ more intimate mixtures of the basic constitutents with the sintering aids, if such aids are necessary to promote sintering (see also Table 2).

\section{Densification behaviour of SHS-derived powders and properties of the sintered products}

Let us pass now in review the densification behaviour of SHS-derived powders, starting with powders of $\mathrm{SiC}$ and $\mathrm{Si}_{3} \mathrm{~N}_{4}$. In both cases SHS produces the $\beta$ forms of the compounds while the the $\alpha$ forms are dominating in the available conventional powders. Figure 6 gives the densities on pressureless sintering for one hour of SiC powders with the usual sintering aids in amounts of $0.5 \mathrm{wt} \%$ of $\mathrm{B}$ and $1 \mathrm{wt} \%$ of C. 
The white columns refer to mechanical mixtures of the sintering aids with conventional $\alpha \mathrm{SiC}$, the shadowed ones, respectively, to SHS-derived $\beta$ SiC mechanically mixed with the sintering aids and complex Si -C-B powders synthesized in situ by SHS. The final densities attained at $2150^{\circ} \mathrm{C}$ are given in the left part and these attained at $2200^{\circ} \mathrm{C}$ in the right part of the Figure. The final densities are significantly higher with the SHS-derived powders. Although the conventional powders start to densify at lower temperatures, the ultimate density of the SHS products is significantly higher.

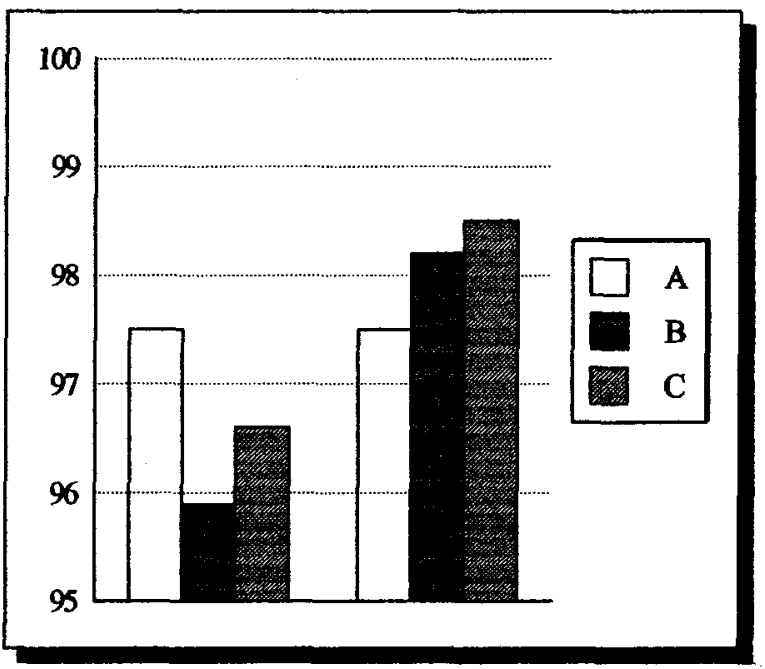

Figure 6. Densities (in \% of the theoretical) attained on pressureless sintering for one hour at $2150^{\circ} \mathrm{C}$ (left side) and at $2200^{\circ} \mathrm{C}$ (right side) of $\mathrm{SiC}$ powders with sintering aids ( $0.5 \mathrm{wt} . \%$ of $\mathrm{B}$ and $1 \mathrm{wt} . \%$ of $\mathrm{C}$ ). A. conventionally produced $\alpha \mathrm{SiC}$ powders, mechanically mixed with boron in form of $\mathrm{B}_{4} \mathrm{C}$ powder; $\mathrm{B}$. SHS-derived $\beta \mathrm{SiC}$ powder mechanically mixed with boron in form of $\mathrm{B}_{4} \mathrm{C}$; $\mathrm{C}$. SiC-B powder synthesized in situ by SHS.

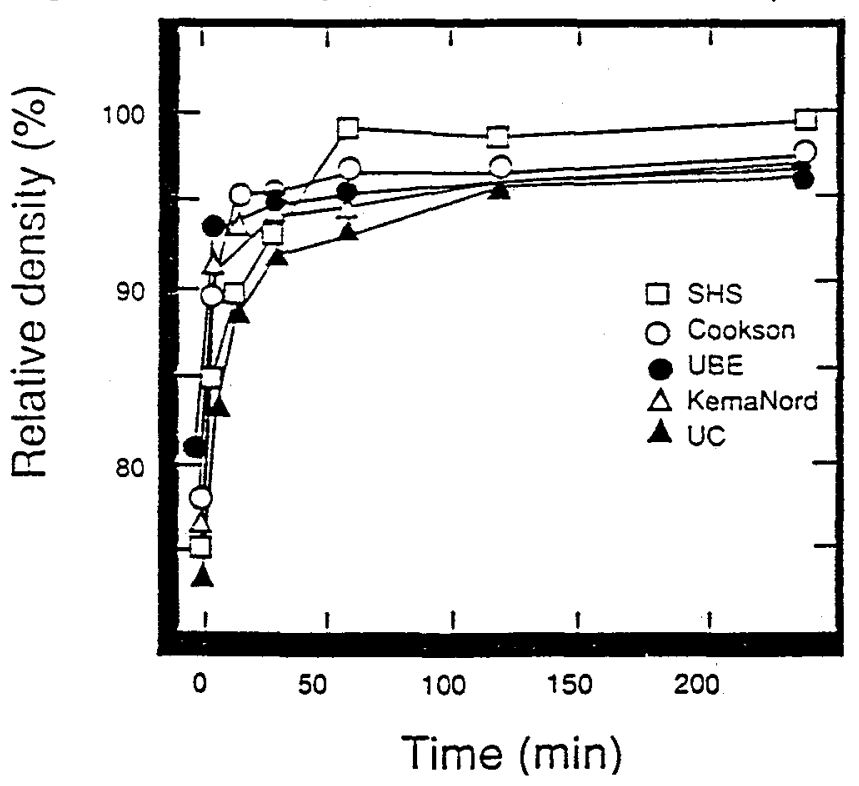

Figure 7. Comparison of densification curves for different $\mathrm{Si}_{3} \mathrm{~N}_{4}$ powders with $6 \mathrm{wt} \%$ of $\mathrm{Y}_{2} \mathrm{O}_{3}$ and 4 wt.\% of $\mathrm{Al}_{2} \mathrm{O}_{3}$ during pressureless sintering at $1630^{\circ} \mathrm{C}$ (after [13]). 
Figure 7 compares the densification curves for different conventional $\alpha$ silicon nitride powders with the ones of SHS-derived $\mathrm{BSi}_{3} \mathrm{~N}_{4}$, during presureless sintering at $1630^{\circ} \mathrm{C}$ with standard sintering aids, $6 \%$ of yttria and $4 \%$ of alumina. The Figure has been taken over from Ref. [13]. On using the SHS-derived $\mathrm{\beta Si}_{3} \mathrm{~N}_{4}$ powders, the final density is significantly higher than with the $\alpha \mathrm{Si}_{3} \mathrm{~N}_{4}$ powders from conventional processing. Here again the densification rate is lower at initial stages of sintering. The higher activity at initial stages of sintering of the conventional $\alpha \mathrm{Si}_{3} \mathrm{~N}_{4}$ may be explained by $\alpha$ - to $\beta$ - phase transformation [13], while the lower final density by the subsequent growth of $\beta$ - silicon nitride grains [21]. The lower ultimate densitites observed on sintering of conventional silicon carbide powders are most probalby associated with similar phenomena. Namely, with the exaggerated grain growth accompanied by pores entrapping that undergoes boron-doped $\alpha \mathrm{SiC}$ at $\mathrm{T}>2100^{\circ} \mathrm{C} \mathrm{[22]}$.

Such processes are insignificant with the SHS-derived powders. This is attested, for example, by the characteristics of sintered $\mathrm{SiC}$ with $\mathrm{C}$ and $\mathrm{B}$ additions produced from SHS-derived powders (Table 2).

Table 2

Comparison of substrates and sintered products in the SiC-B system in case of the processing involving SHS and of the conventional ceramic processing [23][24][25][26]

\section{SHS}

1.Powders for sintering: produced in situ from Si:B:C mixtures, a homogeneous material in the $\mathrm{nm}$ scale. constituted by microdomains of cristalline $\beta \mathrm{SiC}$ and of amorphous phases with a short-range order similar to $\mathrm{B}_{4} \mathrm{C}$.

2. Density attained by pressureless sintering: $98.5 \pm 0.6 \%$ of $\mathrm{TD}$ after $1 \mathrm{~h}$ at $2200^{\circ} \mathrm{C}$.

3. Properties of the sintered products: $\mathrm{K}_{\mathrm{k}}=5.22 \mathrm{MPam}^{12} ; \mathrm{E} / \mathrm{H}_{\mathrm{k}}=18$.

4. Microstructure of the sintered products: Homogeneous in the $\mu \mathrm{m}$ scale with nearly equiaxial grains of $\mathrm{SiC}$ and $\mathrm{B}_{4} \mathrm{C}$ of medium size. elongated $\mathrm{SiC}$ grains.

\section{Conventional processing}

1.Powders for sintering: heterogeneous mixture of $\alpha \mathrm{SiC}$ grains , $\mathrm{C}$ particles and particles of amorphous $\mathrm{B}$ or $\mathrm{B}_{4} \mathrm{C}$.
2. Density attained by pressureless sintering: $97.5 \pm 0.5 \%$ of TD after $1 \mathrm{~h}$ at $2200^{\circ} \mathrm{C}$.

3. Properties of the sintered products: $\mathrm{K}_{\mathrm{kc}}=4.8 \mathrm{MPam}^{1 / 2} ; \mathrm{E} / \mathrm{H}_{\mathrm{k}}=13.0$.

4. Microstructure of the sintered products:

Heterogeneous in the $\mu \mathrm{m}$ scale; with large,

The more homogeneous composition of the SiC-boron powders produced in situ by SHS leads to a more homogeneous microstructure of the sintered products than in case of the conventional powders and processing. It is interesting to note that the SiC-B powders formed in situ may be used to produce materials with high boron contents up to $20 \mathrm{wt} \%$ [27]. This is important because the SiC-B powders transform on sintering to a $\mathrm{SiC}_{-} \mathrm{B}_{4} \mathrm{C}$ particulate composite that ranks among the hardest materials available.

A more homogeneous composition of the starting SHS-derived powders is also most probably responsible for the higher ultimate densities and better properties of $\mathrm{Si}_{3} \mathrm{~N}_{4}-(17 \mathrm{wt} \%) \mathrm{SiC}$ particulate composites. This is illustrated in Figure 8 based on data from Ref. [28].

The examples cited show that due to the specific reaction mechanism SHS is able to produce carbide and nitride powders that allow to attain a high density and a homogeneous microstructure of the sintered materials. Improved properties of these materials should be the result. 


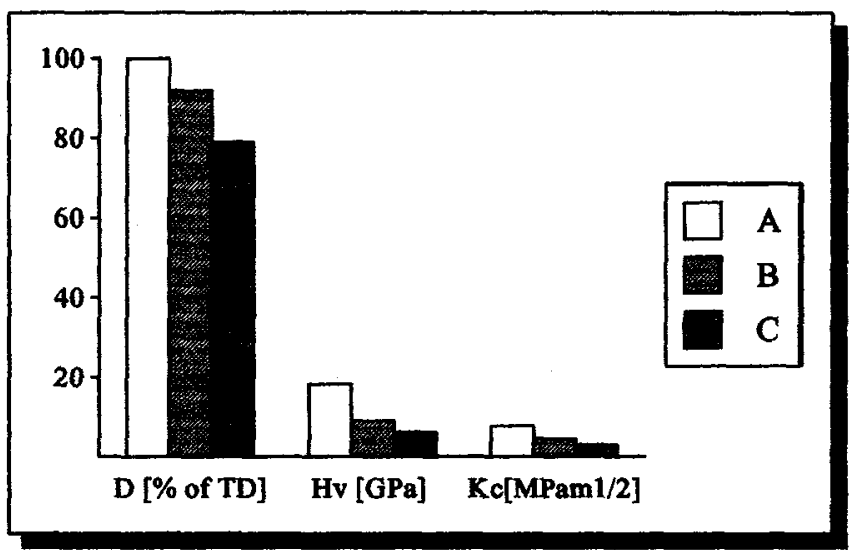

Figure 8.The final density (D), Vickers microhardness $\left(\mathrm{H}_{\mathrm{v}}\right)$, and fracture toughness $\left(\mathrm{K}_{\mathrm{lc}}\right)$ of $\mathrm{Si}_{3} \mathrm{~N}_{4}-\mathrm{SiC}$ particulate composite produced by hot pressing under $21 \mathrm{MPa}$ for one hour at $1700^{\circ} \mathrm{C}$. A. $\beta \mathrm{Bi}_{3} \mathrm{~N}_{4}-\mathrm{SiC}$ material produced in situ by SHS; $\mathrm{B}$. mechanically mixed $\mathrm{\beta Si}_{3} \mathrm{~N}_{4}-\mathrm{SiC}$; C.mechanically mixed $\alpha \mathrm{Si}_{3} \mathrm{~N}_{4}-\mathrm{SiC}$ (after [28]).

The sinterability of powders is even more enhanced when SHS in carried out in systems where extensive solid solutions occur. This is the case of the SiAlONs. Lis et al [29] have reported that theoretically dense $\beta$ and $\alpha / \beta$ SiAlON materials can be produced by pressureless sintering of SHSynthesized powders at temperatures of $1500-1550^{\circ} \mathrm{C}$. These temperatures are significantly lower than the ones which must be used to densify conventionally prepared powders.

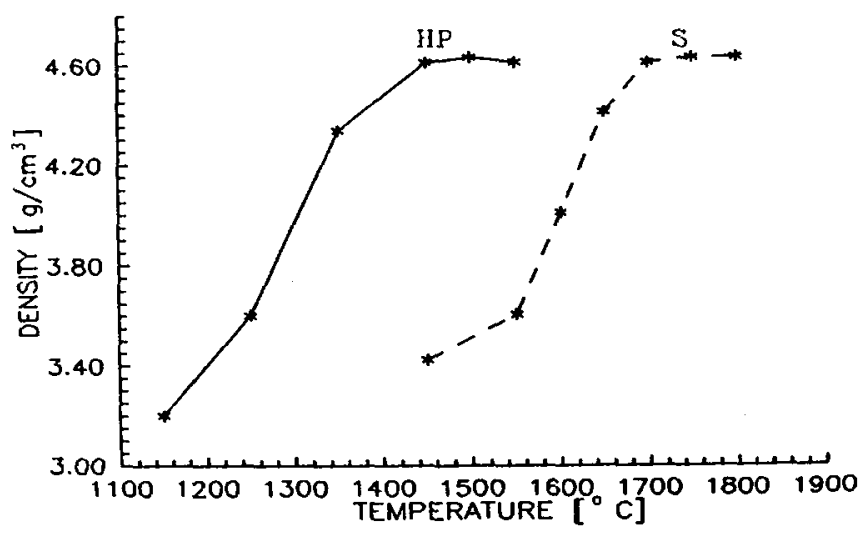

Fig.9 Densification behaviour of SHS-derived $\mathrm{Ti}_{3} \mathrm{SiC}_{2}$ powders on hot pressing under $24 \mathrm{MPa}$ for 15 minutes (HP) and pressureless sintering for 2 hours (S), after [26].

Another system in which occur large ranges of solid solutions is Ti-C-Si. There exists in this system a complex phase, $\mathrm{Ti}_{3} \mathrm{SiC}_{2}$, It combines the usual high-temperature properties of ceramics with a plasticity at room temperature matching the one of constructional hard steel. Conventional furnace methods failed to synthesize this phase, and its synthesis by CVD resulted in insignificant amounts. SHS enabled a synthesis of $\mathrm{Ti}_{3} \mathrm{SiC}_{2}$ in sizable amounts [30][31][32][33]. This warrants a use of powders of this phase in 
ceramic processing. Figure 9 shows the densification behaviour of SHS-derived powders of $\mathrm{Ti}_{3} \mathrm{SiC}_{2}$ Soaking temperatures of $1450^{\circ} \mathrm{C}$ on hot pressing and of $1700^{\circ} \mathrm{C}$ on pressureless sintering, respectively, are sufficient to attain a density above $95 \%$ of the theoretical. These temperatures are unusually low for a carbide phase, and indicate the advantages of SHS in producing complex phases.

\section{Conclusions}

Contrary to opinions that still continue to be heard, it has been shown that the properties of the SHS-derived nitride and carbide powders are significantly better than with the conventionally produced ones. This pertains both to the densification of the powders and to the homogeneity of the sintered products. In addition to economy of energy and simplicity of installations in producing the powders by SHS, this makes the method a very attractive one for the ceramic industry.

\section{References}

[1] McCAULEY J.W., Ceram.Eng.Sci. Proc. 11 (1990) 1137.

[2] MERZHANOV A.G. , BOROVINSKAYA I.P., Dokl.Akad.Nauk SSSR 204 (1972) 366.

[3] MERZHANOV A.G., in Combustion and Plasma Synthesis of High Temperature Materials, Z.A.Munir, J.B.Holt (eds.), VCh Publ. Weinheim-New York (1990), pp.1.

[4] MUNIR Z.A., ANSELMI-TAMBURINI U., Mater.Sci.Rep. 3 (1989) 277.

[5] PAMPUCH R., LIS J., STOBIERSKI L., Science of Ceramics 14 (1988) 15.

[6] MIYAMOTO Y., TAMIKATA K., MATSUZAKI Y., MA X., Int. J. of SHS 1 (1992) 147.

[7] PAMPUCH R., STOBIERSKI L., Ceram.Intern. 17 (1991).

[8] SPRIGGS R.M., STANGLE G., Proc.Intern.Symp.on SHS, Alma-Ata, October 1991.

[9] MUNIR Z.A., Am.Ceram. Soc. Bull. 67 (1988) 342.

[10] CUTLER R.A., RIGTRUP V.M., J.Am.Ceram.Soc. 75 (1992) 36.

[11] PAMPUCH R., LIS J., STOBIERSKI L., RACZKA M., Mat.Res.Bull. 22 (1987) 1225.

[12] PAMPUCH R., LIS J., STOBIERSKI L., J.Am.Ceram.Soc. 72 (1989) 645.

[13] LIS J., MAJOROWSKI S., PUSZYNSKI, J.A., HLAVACEK V., Am.Ceram.Soc.Bull. 69 (1990) 496.

[14] PAMPUCH R., LIS J., STOBIERSKI L., in Combustion and Plasma Synthesis of High-Temperature Materials, ZA. Munir, J.B..Holt (eds), VCh Weinheim-New York (1990) 211.

[15] ALEKSANDROV, A.A., KORCHAGIN M.A., BOLDYRYEV V.V., Dokl. Akad.Nauk SSSR, Fiz.Khim. 292 (1987) 114.

[16] PAMPUCH R., WALASEK E., BLAłOSK6RSKI, J., Ceram.Intern. 12 (1986) 99.

[17] STOBIERSKI L., LIS J., PAMPUCH R., Ceram.Papers Polish Acad.Sci. 38 (1989) 5.

[18] SHTEINBERG, A.S. , pers. comm.

[19] KIRDYASHKIN A.I., MAKSIMOV Y.M., NEKRASOV E..Fiz.Goreniya $i$ Vzryva (russ.) 17 (1981) 377.

[20] MASLOV. V.M., BOROVINSKAYA I.P., MERZHANOV A.G., Fiz.Goreniya i Vzryva (russ.), 12 (1971) 631.

[21] LEE D., KANG S.L., PETZOW G., YOON D.N., J.Am.Ceram.Soc. 73 (1990) 767.

[22] PROHAZKA S., in 'Silicon Carbide 1973', Marshall R.C.(ed.), University Press, S.C. (1974).

[23] PAMPUCH R., L'Industrie Ceramique (in print).

[24] STOBIERSKI L., PAMPUCH R., ERMER E., LIS J., Ceram.Intern. 19 (1993).

[25] BIAłOSKóRSKI J., PIEKARCZYK J., 3rd Conf. Europ.Ceram. Soc. Madrid, Sept. 1993 (in press).

[26] LIS J., PAMPUCH R., STOBIERSKI L., ERMER E., ibid. (in press).

[27] STOBIERSKI L., PAMPUCH R., ERMER E., LIS J., ibid.(in press).

[28] AGRAFIOTIS C.C., LIS J., PUSZYNSKI J.A., HLAVACEK V., J.Am.Ceram.Soc. 73 (1990) 3514.

[29] LIS J., MAJOROWSKI S., PUSZYNSKI J.A., HLAVACEK V., Am. Ceram.Soc. Bull. 70 (1991)1658.

[30] PAMPUCH R., LIS J., STOBIERSKI L., TYMKIEWICZ M., J..Europ.Ceram.Soc. 5 (1989) 283.

[31] PAMPUCH R, LIS J., PIEKARCZYK J., STOBIERSKI L., J.Mat.Synth. and Proc. 1 [2] (1993).

[32] PAMPUCH R., LIS J., STOBIERSKI L., Intern. J.o of SHS 1 (1992) 78.

[331 LIS J.. PAMPIJCH R.. STOBIERSKI L.. Intern. .J. of SHS (in nrint). 